\title{
Iris Melanoma pT1b TNM Finding v8
}

National Cancer Institute

\section{Source}

National Cancer Institute. Iris Melanoma pT 1b TNM Finding v8. NCI Thesaurus. Code C140620.

Iris melanoma with tumor limited to the iris, more than 3 clock hours in size. (from AJCC 8th Ed.) 